\title{
Notes on Greek Inscriptions from Sandahannah
}

\section{A. Stuart Murray}

To cite this article: A. Stuart Murray (1901) Notes on Greek Inscriptions from Sandahannah, Palestine Exploration Quarterly, 33:1, 59-60, DOI: 10.1179/peq.1901.33.1.59

To link to this article: http://dx.doi.org/10.1179/peq.1901.33.1.59

曲 Published online: 20 Nov 2013.

Submit your article to this journal

III Article views: 4

Q View related articles $\sqsubset$ 


\section{NOTES ON GREEK INSCRIPTIONS FROM SANDAHANNAH. \\ I.-By A. Stuart Murray, LL.D. \\ Arsinoè the Great.}

IN the October Quarterly. Statement, p. 334, there is a Greek inscription which I would read conjecturally thus:-

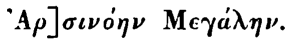

$$
\begin{aligned}
& \delta] \omega \rho[\epsilon \dot{a} \nu] \tau \dot{\eta} \nu . \dot{\epsilon} \gamma \beta a \sigma \iota \lambda \epsilon^{\prime} \omega \mathrm{s} \\
& \text { iai] } \beta a \sigma i \lambda i \sigma \sigma \eta s
\end{aligned}
$$

"Arsinoè the Great. Gift of the King and Queen."

The pillar on which the inscription occurs was apparently the base of a statue of $\Lambda$ rsinoè, who is here styled "the Great," a title not unfrequently appliea to the Ptolemaic kings. The inscription accordingly belongs to the Seleucid ruins, and is of great importance. A paper impression of it is highly desirable.

Inscriptiou No. 2 , on p. 335, records an offering, not by Crato, but by a son of Crato.

\section{II -By Colonel C. R. CONder, R.E. \\ Berenice.}

The dedication to Apollo connected with the name of Queen Berenice-found at Tell Sandahannah-is in characters which may easily be supposed as late as the Herodian period. I do not know on what grounds it is attributed to the Seleucid age. "Queen Berenice" was the sister of Agrippa II, before whom St. Paul appeared at Cæsarea. There is notbing strange in her being connected with a pagan text, since the Herodians erected temples to pagan gods. Sandahannah, I believe, really means "St. John" and not "St. Anne," for it is close to Beit Jibrin, which, in the twelfth century, belonged to the Knights of St. John. 


\section{III.-By W. H. D. Rouse, Esq.}

The word Kpátw'os in the inscription on p. 335 of the Quarterly Statement for 1900 is not the name of the dedicator, which must he in the nominative. The last letter of it (s) appears just before Kátwvos, "son of Craton."

RugBr, Octoler 14th, 1900.

\section{JAR-HANDLE INSCRIPTIONS.}

I.-By Professor Theovore F'. Wrighte, Ph.D.

The inscribed jar-handles which have been found in excavating Tell es-Sàfi and veigbbouring sites could not receire adequate attention in the field while the work was going on, and should now come before students at their homes, especially if they have access to other handles of like character. I offer a fow remarks on the subject, and hope that others will contribute what they know:-

1. This is not a new subject or a recent one. The Quarterly Statement, No. 7, 1869-1870, has on p. 372 an unsigned note which speaks of jar-haudles found by (then) Captain Warren, "all of which were stamped with the same mark-apparently an eagle, rudely designed." They bore letters "similar to those of the Moabite Stone." Three of these handles were read by Dr. Birch, of the British Museum, and are given in English as "Le Me LeK $\mathrm{ZePHa}-\mathrm{LeK}$ Shat-LeK," showing that they were similar to those found by Dr. Bliss as regards the first word. No doubt the anthor of "Underground Jerusalem" referred to this when he wrote on p. 422 of that work :-

"At this angle [the south-east corner of the wall, near bottom of the 80 fert shaft $j$ were found those pottery jar-handles on which is inpressed a winged sun or disc, probably the emblems of the Sun-God; around this are characters which denote that this pottery was made for royal use. Now this is the south-east corner of Solomon's Palace, and what more natural than that some of the pottcry from the palace should here accumulate?" 